\title{
Da'wah of Digital Era \\ Applicative Study: Qs. An-Nahl: 125 on Millennial Generation
}

\author{
Muhammad Raihan Nasution \\ State Islamic University of North Sumatera (UINSU), Medan, Indonesia \\ samihahnasution28@gmail.com
}

\begin{abstract}
In this digital era, young people are very vulnerable to negative things, therefore Islam as a religion which is rahmatan lil alamin, must take appropriate and fast actions to save young generations of Islam from getting lost in the darkness of cyberspace life. This article is prepared with a library research approach by conducting a literature review and collecting data from various sources and subsequently, the data is analyzed descriptively by presenting facts or findings which are then theoretically reviewed. Therefore da'wah of digital era really must use the media, especially new media. The development of communication technology has changed the way people communicate and interact. Nowadays, almost everyone uses the internet to send, search, and read information. Therefore, the Qur'an Surah An-Nahl: 125 offering da'wah methods of digital era have to be able to attract sympathetic Millennials, presenting representative, interactive and innovative da'wah methods through social media is the best way to save the young generations of Islam in the future.
\end{abstract}

Keywords : da'wah; digital; millennial generation

\section{Introduction}

Nowadays, the challenge of Muslims is no longer fighting against colonial countries. That was the challenge of a century to seven decades ago, when colonialism was still part of interconnection between nations. Challenges in the digital era, of course are very different with complexity such as economic warfare, ideology, cross-national diplomacy, identity contestation.

We live in a different layer with KH. Hasyim Asy'ari, KH. Ahmad Dahlan, Kiai Wahid Hasyim. We dive into the life of a nation with all conflicts, cross changing problems, to attract interests, which may be more complicated than what happened in the past. But, every era has a complicated problem, each has a different challenge. At this point, the ulema and scholars always find momentum.

Today we live in an era where digital penetration and innovation are part of a gift as well as a disaster for humans today. We live in an era where religious narratives are recorded in a different way than seven decades ago.

The younger generation of Islam will enter the challenges of the world that accelerates technological innovation, as well as the growth of giant companies in the digital field, researches to create sophisticated machines equipped with artificial intelligence (AI) that greatly enhance humans.

Then, for the millennial generation, how is true da'wah today? Indonesia is facing a challenge era in the form of massive technology penetration which missives, but has not been accompanied by significant digital literacy. The biggest challenge for the Muslim nation is how to use creativity in the field of technology, media innovation, and its sophistication to support equal benefits. If we are not able to overcome the tidal wave of technology, then the disaster is facing before our eyes, ready to be swallowed by the tidal wave of the digital era.

Indonesia has also become a laboratory for sowing innovations for generations of creative Islam. In this digital era, young generations who are ready to work hard, innovative, istiqamah with their leadership will be able to open the door for the future of themselves and the people. 
In this digital era, with such extensive internet users, both geographically and era, it allows Indonesia as a giant in the field of digital economy.

For this reason, today we see that there have been many growing houses of Tahfizh, and centers of Islamic civilization in every line of science, various models of da'wah and learning methods for the holy book of Al-Qur'an have been supported by academics and scholars in trying to grow this digital era.

However, it is not enough, the young generation of Islam today and in the future is challenging, which is totally different from what the ulema or Walisongo championed in developing Islam in Indonesia. We must squeeze the essence of the nation's heroes and their example to be transformed in the present. Hard work, creativity, determination, solidarity, as well as integrity as part of the Indonesian nation must be had in the fight for strength and creativity in this era.

Seeing this situation, some Muslims feel the disaster that befell them. They rose again to awaken the Muslims for the negligence they did. They fought back to revive Islamic da'wah. From the reviews of the history of Muslims, we know how their struggle and enthusiasm in upholding the religion of Allah, let us look at the development of Islam in this digital era. In an era like this, the light of Islam must be revived there, there are many obstacles and special obstacles from those who are hostile to Islam. It is not uncommon for us to find Muslims still very concerned about the development of Islam and striving as hard as possible in Islam in this challenging era. Various efforts were made and one of the efforts was made by utilizing increasingly advanced information technology. Newspapers, magazines, television, radio, and even the internet have been targeted in da'wah Islam.

Seeing the phenomenon that occurs in the midst of people's lives in this digital era. Therefore, in realizing a very noble mission, da'wah activists will be faced with the challenges of the digital world, because people today are very critical and selective, including critical and selective in accepting da'wah materials, they sometimes question whether da'wah materials it fits their needs or not.

\section{Review of Literature}

\subsection{Definition of Da'wah}

Da'wah is a very important activity in Islam, with da'wah, Islam can be spread and accepted by humans. On the contrary, without da'wah Islam will be further away from society and then it will disappear from the surface of the earth in people's lives. Da'wah functions to organize a religious life towards the life of a harmonious and happy society, Islamic teachings that are broadcast through da'wah can save people and society in general from things that can lead to destruction. ${ }^{1}$ Etymologically the word da'wah comes from Arabic, which is the form of masdar from the word da'a-yad'u which means calling, inviting or calling. ${ }^{2}$

From the languera point of view the word da'wah comes from Arabic da'a which means calling, asking, guiding, herding or calling, inviting other people to follow, join, and understand to have an action and the same goal that is expected by the attacker. ${ }^{3}$ And da'wah also means

\footnotetext{
${ }^{1}$ Mohammad Ali Aziz, Ilmu Dakwah,(Jakarta:Kencana, 2006), p. 37

2 Ibrahim Unais dkk,Al-mu'jam al-Wasith,(Cairo:al-Majma' al-Lughat al- ‘Arabiyah,1972),Jil: 1.p.286-287. Toha Yahya, Omar, Ilmu Dakwah, (Jakarta: Wijaya,2004), p. 67

${ }^{3} \mathrm{Sad}$ 'Ali Ibn Muhammad al-Qohthoniy.fiqhu al-da 'wah fi shahîh al-Imam al-Buhkariy, Maktabat Syamela.
} 
call, invitation, call, invitation, and defense, petition (do'a). ${ }^{4}$ In an integralistic sense, da'wah is a continuous process that is handled by the bearers of da'wah to change the goal of da'wah in order to be willing to enter the path of Allah, and gradually towards an Islamic life. ${ }^{5}$ Whereas according to Amin Rais that Da'wah is every effort to reconstruct the community which still contains elements of ignorance in order to become an Islamic society. ${ }^{6}$

Whereas in terms of terms, there are several meanings, among others, da'wat ila Allah is intended to call for faith in Allah, believe in what was brought by His apostles, call to believe what the apostles preached and obey anything what they ordered. It includes a call to say two creeds, perform prayers, zakat, fast the month of Ramadan and Hajj, and include calls for faith in Allah, faith in His apostles, faith in the day of resurrection, qadha 'and qadar, and calls for the servant worshiped his Lord as if he saw him. ${ }^{7}$ Briefly as revealed by Abdul Karim Zaidan; what is meant by da'wah is to call upon Allah, and the intention is to call upon the religion of Allah, namely Islam. ${ }^{8}$

\subsection{Da'wah Method}

The method comes from the word metodos (Greek) which means a way that can be traveled. In Arabic call it tariqah which is a neat and well thought out way to achieve a purpose. The system or technique comes from the word sistema (Greek) which means that a whole organization is organized that moves towards a specific goal. In Arabic translating the system with uslub or manhaj. So the method of da'wah is the adjustment of the way with material (content) according to the situation and condition of the object, suitable with the location and attitude of da'i to achieve the purpose of da'wah. ${ }^{9}$

Da'wah method (Approach) is the ways done by a communicator to achieve a certain goal on the basis of wisdom and affection. ${ }^{10}$ Method is a plan or procedure that is attached to complete an activity or task for the achievement of goals. method is a systemic way of working to facilitate implementation to deliver a material. The method means the way that has been arranged and through the thought process to achieve a purpose. And how to understand work also explains objects with the study of da'wah science. Da'wah techniques are where methods are used to implement methods. According to 'Abd al-Karim Zaidan, the method is related to how to carry out the delivery of da'wah messeras and overcome obstacles. ${ }^{11}$

In conclusion the method is a systemic way of working to facilitate implementation to deliver a material. In addition to da'wah by means of wisdom, in the Qur'anic explanation al Nahl is also called da'wah with the method of mau'izhah hasanah. ${ }^{12}$ then there are three elements that must be met in this method. First, the mission of mau'izhah hasanah must contain elements of advice. Second, the advice can be soothing. Third, the advice does not contain elements of criticism and insults that make people deter to hear it.

\footnotetext{
${ }^{4}$ Awaluddin Pimay, Paradigma Dakwah Humanis, (Semarang: Rasail,2005), p. 13

${ }^{5}$ Didin Hafidhuddin, Dakwah Aktual, (Jakarta: Gema Insani Press, 2000), p. 77

${ }^{6}$ Amien Rais,Cakrawala Islam Antara Cita dan Fakta, (Bandung: Mizan,1999), p. 25

${ }^{7} \mathrm{Sad}$ 'Ali Ibn Muhammad al-Qohthoniy. fiqhu al-da 'wah....,

${ }^{8}$ Abdul Karîm Zaidan, U’shûlu al-da'wah, versi e-book, 1975, p, 3.

9 Jamaludfin Kafie, Pengantar Ilmu Dakwah, (Madura: Karunia Surabaya,1988), p. 67.

${ }^{10}$ Toto Tasmara, Komunikasi Dakwah, (Jakarta: Gaya Media Pratama, 1997), p. 43.

${ }^{11}$ Ibid., p. 357

${ }^{12}$ Da'wah of mau'izhah hasanah is da'wah with gentle words that are nuanced by friendship (al-rifq). Thus as much as possible avoid rude, fierce and painful expressions (qaswat al 'ibarat).
} 


\subsection{Understanding Millennials}

The word millennial may be less popular with some people. But among adolescents, students and students this word is quite popular and even becomes the subject of discussion and discussion. Phenomena that can be seen from daily activities, habits, dependence on the internet, individual character, selfishness, narcissism, existence, mental vulnerability and so on. The dependence of society on the sophistication of technology, information, and transformation is seen as a medium or tool to facilitate its activities. On the contrary, today's information technology can also be a scourge for many people because it is considered not in accordance with existing rules or norms. Conditions like this cause social problems that arise from the habits of modern society.

The millennial generation is currently a concern of all circles. Millennials are often discussed in all aspects, both in terms of behavior, association, education, norms, social awareness, mental conditions, including dependence on the use of technology. This is due to changes in the way of life with previous generations. This very dominant change led to the birth of attitudes, ideologies, and understandings that were very different from previous generations. The millennial generation is considered a carrier of negative values because the influence consumed comes from outside. Millennials are very open to technology and something new that blends digital, modern like the ownership of smartphones with all the latest features offered, be it facebook, youtube, twiter, Instagram, whatshap, Hugo and so on are the most widely used media by the millennial generation .

The positive side of social media if used wisely will bring many benefits that can be obtained for its users. Through the applications offered, people are now facilitated in the process of communication, transactions. Communication no longer depends on distance and time, and costs are cheaper. Social media can also be used as learning media, such as the use of videos related to the material taught we can get through the applications offered. A variety of tutorials about learning, development, skills are also available through the applications available on each smartphone's Android users.

The duration of time spent using social media for almost 24 hours is not only presenting accurate information, there is also a negative side of the media, namely the existence of various modes of crime, fraud that is intensified by irresponsible individuals. The spread of hoaxes, videos that are not worth watching, dissemination of ideas that disturbs the community becomes a social problem that is difficult to deal with in a real way. In addition, the user limits of these applications are not fully controlled so underera children have seen actions that they should not see. Conditions like this almost cover every activity that occurs in cyberspace. Finally, human mentality is slowly changing, both quickly and slowly.

Religion and customs that become social control seem to have been abandoned by young people, the social values that were once hailed seemed to have been lost to the times. Today's Millennial Generation puts forward rationalism and selfishness in addressing things. When they fail to understand something because of their egoism, emotions that will emerge surface, anger, insults, insults, brutal acts become a common spectacle today. Most severely when Islamic values that have been the pride of Muslims are slowly poisoned by thoughts that aim to mislead the Ummah.

Modern words are used as a pretext, while religion is seen as something old-fashioned or outdated. Modern is recognized when humans today are able to live like westerners in all aspects of their lives. Modern is recognized if it is able to behave like that of many people, no longer based on religious values or traditional values. Apart from the negative influences that 
are considered to dominate the millennial generation, there is another side that refutes this condition. Behind the inherent negative label, the Millennial Generation considers the progress that is happening now to be used optimally. The sophistication of information, transportation, and technology media answers all human needs today. Loss if it is not part of this progress. Through one button available on the computer screen, cellphone and other electronic media human work is made easier. Work that was done in a matter of hours, days, and even weeks, can now be done for several minutes by pressing the control button. Such sophistication is a matter of pride for the millennial generation, the ancient learning process was only carried out in schools and at certain hours, at this time students were able to access through existing media without any limitation of hours and places. Books are also not only in paper form, e-books are now available.

Today's digital technology is inseparable from positive and negative impacts, the positive and negative effects of technological advancements are now an active boomerang on all sides. When progress is considered as a mecca for millennial generations. The mecca of freedom, the mecca of truth, the concept of modernity is considered as what most people do. Even though not everything that many people do is always right. There are times when the truth will become foreign because few people understand and implement it. Not understanding the millennial generation of values that exist in Islam results in them running away from the true truth. Blaming Islam as an obstacle to progress, curbing freedom, creating hostilities, terrorism, and others. All of these opinions are consumed by millennials through the media currently available. Religion is considered as something that gives birth to discrimination for adherents. This is a huge homework for Muslims to rectify this understanding.

Islam as a religion of rahmatallil amin alamin has never bound Muslims to advance. Islam comes like light when darkness covers the universe. Islam comes like rain in the desert that brings coolness and peace to others. Islam has never shackled human creativity at this time. Islam only provides clear signs about a case so that it is not wrong to react to it. Islam has never chosen family, property, power and others. Islam views all human beings as having the same position, only faith becomes the difference. So, it is a big mistake when the majority of assumptions that claim that Islam is an obstacle to current progress. The lack of understanding of the millennial generation of the values that exist in Islam causes it to run away from the truth.

Blaming Islam as a barrier to progress, curbing freedom, creating hostility, and various labels (streotive). All of these opinions are consumed by millennials through the media currently available. Millennials are advancing in terms of the use of sophistication that is present today. But to balance its use must remain in accordance with the norms that exist in Islam. There are signs that must be used as guidelines in the use of technology. In addition, individualism, selfishness, hedonism, Maxism which dominates the millennial generation will be minimized through religious approaches. Understanding good religion for the millennial generation will make it truly human. Believing in the truth of Islam, aware of its individual and social needs. Life is not only for promoting selfishness, but the ability to accept the existence of others is also important. Individualism is also not an essential Islamic teaching, Islam tells its followers to be brothers and sisters, to be in submission, please help in kindness and not help in evil.

The approach of religion or da'wah to the millennial generation must also be done through the use of communication media because the most users are millennials. Da'wah through the use of communication media and technology will be easier to achieve the target 
because different generations are different ways of approach used. At present there are da'i-dai which have their own characteristics, ranging from material, style, rhetoric, performance, and so on. Millennials have been given the choice of what they will look for, what style they will follow, what materials they need, all of this they can get through the available sites. When is the time, how long, where can everything be arranged by the millennial generation because all of these options are available.

\section{Research methods}

This article was compiled with a literature study approach by conducting literature studies and collecting data from various sources such as journals, documentation books, literature, and the internet, and continued by finding relevant theoretical references to the problems found. Furthermore, the data is analyzed descriptively by presenting facts or findings which are then theoretically reviewed.

\section{Discussion}

\subsection{Da'wah in the era of the Prophet Muhammad SAW}

Da'wah at the time of the Prophet Muhammad SAW when the revelations from Allah go through the angel Gabriel to the Prophet Muhammad in Surat Al-Muddatsir.

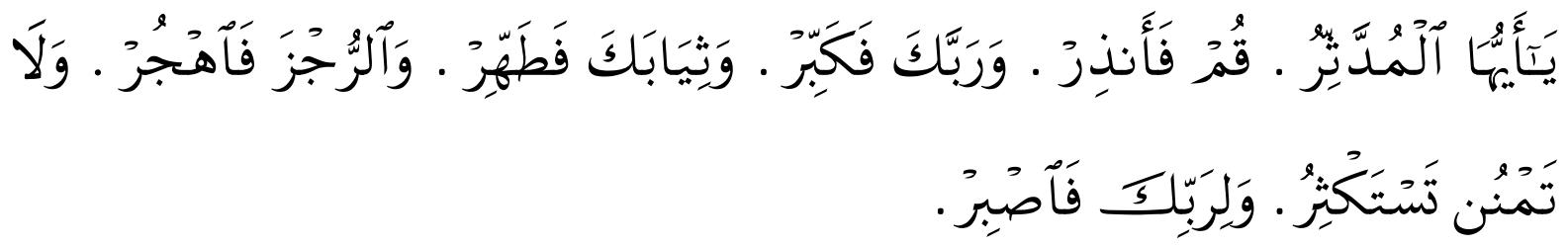

Meaning: "O you who covers himself [with a garment]. Arise and warn. And your Lord glorify. And your clothing purify. And uncleanliness avoid. And do not confer favor to acquire more. But for your Lord be patient."

When the verse came down, the Prophet began to deliver the messera of da'wah to his close relatives and those around him with clandestinely. The people who claim to convert to Islam for the first time are:

1. His wife, Khadijah binti Khuwailid

2. Adult group, Abu Bakar as-Sidiq

3. The children's group, Ali bin Abi Talib

4. The group of servants is dangerous, Zaid bin Harithah

The Islam of these people brought the impact of Islam to other friends such as Uthman ibn 'Affan, Zaid bin Tsabit, Abdurrahman bin Auf, Talha bin Abdullah, Arqam bin Arqam and many others besides them. After many friends who declared themselves following the Prophet, began the teachings of Islam delivered at the house of a friend named Arqam bin Arqam. In that house he delivered and taught revelations from God. After the truth of the teachings of Islam appeared, more and more friends followed in the footsteps of him entering Islam.

After three years the da'wah of the Prophet was carried out clandestinely, then a revelation from Allah came down to preach openly. Allah says: 


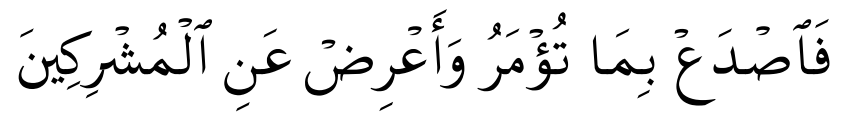

Meaning: "Then declare what you are commanded and turn away from the polytheists."

With all his courera and obedience to God, he began to call on Islam to all humans to give warnings and good news. Explained in hadith sahih.

From Ibn Abbas r.a he said: when going down the verse (and giving a warning to your closest family) Rasulullah come out to Shaffa Hill and up to the hill. So all the people gathered together and Rasulullah said "O Bani, O Bani, O Bani Abdul Manaf, if I say behind this hill there is enemy who attack us do you will believe it? They said: of course, we never found you lying. So he said: in fact I was sent to you to deliver a warning and between my hands there was a tremendous adzab. Suddenly Abu Lahab said: "Woe to you O Muhammad, have you gathered us only for this?"

At that time the revelation from Allah in the surah Al-Lahab came down as a warning to Abu Lahab that he was the one who was wretched. When da'wah openly began, many parties were hostile to the Prophet. They tortured Muslims from the weak class to get out of Islamic teachings such as Yasir, Amar, Sumaiyy ah, Bilal and many more. But they remained steadfast in their faith and were patient with all the torment that had befallen them.

Seeing the many Muslims who were victims of the atrocities of the Quraish infidels, Allah's order came down to migrate to Medina. A new life began for the Muslims of Mecca in Medina. They are willing to leave their wealth and family in order to follow the Prophet to the true teachings. When he arrived in Medina, the first time that the Prophet did was build a mosque for the sake of worship and da'wah which was then given the name of the mosque of An-Nabawy.

The Prophet instilled in the Muslims to strengthen the brotherhood, distance themselves from hostility. Every Muhajirin is in a congregation with the Ansar. With such brotherhood, their brotherhood grew stronger so that the followers of the Prophet more and more. ${ }^{13}$ In addition to teaching religion and sharia law, the Prophet also taught the friends how to fight and confront the enemy. It is said that there were many wars which had been experienced by Muslims against the infidels among the Battle of Badr, the Battle of Uhud, the Battle of Khandaq and other wars. Until the end of his life, it was stated that there were 27 wars in which accompanied the Prophet and 38 wars in which not accompanied by the Prophet.

\subsection{Da'wah Strategy among Millennial}

Before discussing da'wah in the digital era, we discussed first about the main components / elements of da'wah as an effective communication system in the process of carrying out da'wah. Therefore, da'wah in modern times is da'wah carried out by observing the important elements of the da'wah, then the subject or interpreter of the da'wah adapts the material, methods and media of da'wah to the conditions of modern society (as da'wah objects) which may be situations and conditions that occur in modern times, especially in the area of diversity, it had never happened before, especially in classical times.

\footnotetext{
${ }^{13}$ Akram Dhiya' al-'Umary, Al-Mujtama' al-Madny fi 'Ahd an-Nubuwah,(Madinah,al-Majlis al-I'lamy,1983),
} p.71-76. 
Thus, da'wah in the digital era is da'wah whose implementation is adapted to the conditions and conditions of modern society, both in terms of material, methods and media to be used. Because maybe the material presented is good, but the method or media used is not in accordance with the conditions of modern society, then da'wah will fail. Vice versa, it may be that the media or methods used are in accordance with the conditions of modern society, but the material delivered is not right, especially if the display of the packaging is less attractive, and da'wah will fail.

Therefore, to achieve the goal of effective da'wah in the modern era, preachers should be people who have extensive knowledge and insight, convey the material or content of actual da'wah messeras, using appropriate methods that are relevant to the conditions of the millennial society, and use media communication that is in accordance with the conditions and progress of the millennial community it faces.

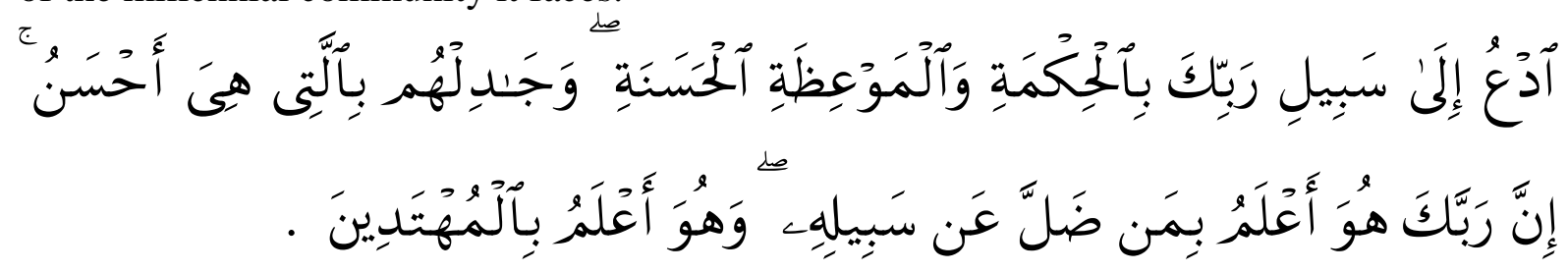

Meaning: "Invite to the way of your Lord with wisdom and good instruction, and argue with them in a way that is best. Indeed, your Lord is most knowing of who has strayed from His way, and $\mathrm{He}$ is most knowing of who is [rightly] guided."14

This verse is understood by the ulema as explaining three types of da'wah methods that must be adapted to the objectives of da'wah. Against scholars who have high knowledge are instructed to deliver da'wah with wisdom, that is dialogue with wise words according to their level of intelligence. Against the laity, they are instructed to apply the will, which is to give advice and parables that touch the soul according to their simple level of knowledge. As for Ahl al-Kitab and the followers of other religions that are ordered, there is no debate in the best way, namely with logic and subtle rhetoric, free from violence and swear.

\subsection{Da'wah in digital}

\section{a. Social media}

One effective target for disseminating Islamic teachings is modern technological tools in the field of information and communication. Progress in the field of information and telecommunications must be used by da'wah activists as a media in carrying out Islamic da'wah, because in this way the teachings of Islam can be received in a relatively short time by the target of propaganda on a broad scale. In this case, there are still many da'wah institutions that have not been able to take full advantage of access to information technology, as well as the provision of modern da'wah.

Social media has become a phenomenon that is increasingly globalizing and entrenched among the people. Social media is the result of advances in Information and Communication Technology whose existence is almost inseparable from human life.

Social media is an online media, where users through internet-based applications can share, participate in, and create content in the form of blogs, IG, forums, social networks, and virtual world space supported by increasingly sophisticated multimedia technology. At present,

${ }^{14}$ JAKIM, Tafsir Pimpinan Ar-Rahman,(Kuala Lumpur:Darul Fikri,2001), p.668. 
social networking, WA, FB, Twitter, YouTube are the most widely used and growing social media among others. ${ }^{15}$

On the one hand, the presence of social media has helped and benefited many people. People in any part of the world can easily interact with a much cheaper cost than by telephone. Besides that, with the existence of social media the dissemination of information is also getting faster. Some other advantages of social media compared to conventional media include:

First, Fast, concise, compact and simple. If we look at it, every conventional media production requires special skills, standardized standards and superior marketing capabilities. Conversely, social media is so user-friendly, even users without an Information Technology (IT) knowledge base can use it. All you need is a computer, tablet, smartphone, plus an internet connection.

Second, creating a more intense relationship. Conventional media only do one-way communication. To overcome this limitation, conventional media tried to build a relationship with the model of interaction or connection live via telephone, and twitter. Whereas social media provides wider opportunities for users to interact with partners, customers, and relations, and build reciprocal relationships directly with them.

Third, broad and global reach. Conventional media has a global reach, but to sustain it, it costs a lot and takes longer. Whereas through social media, anyone can communicate information quickly without geographical barriers. Social media users are also given a great opportunity to design content, according to their targets and desires to more users.

Fourth, controlled and measurable. In social media with a tracking system available, users can control and measure the effectiveness of the information provided through the response back and the reactions that arise. Whereas in conventional media, it still takes a long time. $^{16}$

But there are also negative effects, including; reduced direct interpersonal interaction, causing addiction, as well as ethical and legal issues because the content violates moral, privacy and regulations. So, in the end it gave birth to a new culture in the community about the use of time which is influenced by social media.

Social media users are now not only at leisure, but also at busy times, because they are used as a means to work. The time limit, space and range are lost, so the echoes become widespread without barriers as in the effects of conventional media. Therefore, wisdom in the use of social media must be considered because the impact is difficult to predict, especially if the content violates propriety, ethics, norms of society, culture and others.

The phenomenon of digital propagation is indeed developing along with the development of information technology in the world. The new internet entered Indonesia in 1994. Then around 1998-1999 Islamic sites emerged in Indonesia such as, MyQuran.com, Ukhuwah.or.id, MoslemWorld.co.id, IndoHalal.com and Islamic websites that other. These sites are not only sites of Islamic institutions, but contain various information and facilities that are needed by Muslims and today are not only Islamic sites that appear but also various Islamic applications, from various disciplines needed by society this time.

\footnotetext{
15 Ani Mulyati, Guide to Optimizing Social Media for the Ministry of Trade of RI, (Jakarta: Pusat Humas Kementerian Perdagangan, 2014), p. 2

16 Ibid., p. 31-32
} 
The entry of the Internet in the aspects of life of Muslims began to shift old ideas. Being a santri now does not have to be identified with a sarong and the Koran is broken. The need for self-actualization as a Muslim is as important as da'wah itself.

From a brief discussion of internet usage / social media, one general understanding can be drawn that the Internet is indeed an effective medium for da'wah and disseminating information. Nevertheless the Internet will not be able to replace the role of ulema, kiai and ustadz.

\section{b. Da'wah through Social Media}

In 2014 internet users in Indonesia reached $15 \%$ or 38.2 million of the total population of around 251.2 million. Meanwhile social media users in Indonesia also account for around $15 \%$ of the total population of Indonesia. That is, almost all internet users have social media accounts. These social media users access their social accounts on average around 2 hours 54 and as many as $74 \%$ access their accounts via a smartphone. ${ }^{17}$

Globally, the use of social media shows a growth phenomenon that is difficult to stop. Digital Insights, in September 2013 stated that the number of social media users like Facebook had reached 1.15 billion. Less than four months, precisely at the end of January 2014, The Next Web launched this active social networking octopus user which reached 1.23 billion. Facebook users in Indonesia in 2014 are estimated to reach 80 million or number four in the world. ${ }^{18}$ The data is data in 2014. With this very significant growth, it is certain that in 2016 it has experienced a much more significant increase in the use of social networking by the world population.

It's so massive that humans use the internet and social networks. So, of course it will be very effective if social networking is used as a means to spread goodness (da'wah). Of course all information that has been shared on social media will be directly and easily accessible to anyone and anywhere. Because social media can make people communicate with each other wherever and whenever, no matter how far they are, and don't care about day or night. So by using human social media like communicating directly with each other. It's just that the use and control of social media is still not firm. So that there is still frequent crime in the media.

Therefore, the use of social media must be accompanied by a wise and wise attitude. Using social media wisely will make it easier for someone to study, find work, send assignments, find information, shop, or preach. Conversely, if you use social media with no care, it can also have an impact on bad things.

The Electronic Information and Transaction Law which clearly regulates matters that are prohibited in utilizing social media. As; Defamation is regulated in Article 27 paragraph 3 which reads: "Every person intentionally and without rights distributes and / or transmits and / or electronic documents that have content of insult and / or defamation". Making statements that are provocative and contain SARA elements are explained in article 28 paragraph 2; "Everyone intentionally and without the right to disseminate information intended to cause hatred or individual hostility and / or community groups is based on ethnicity, religion, race and intergroup (SARA)". ${ }^{19}$

\footnotetext{
${ }^{17}$ Ibid., p. 42

${ }^{18}$ Ibid

19 (https://ppidkemkominfo.files.wordpress.com/2012/11/uu-no-11-tahun-2008-tentang-ite.pdf).
} 


\section{Conclusion}

From the description of the discussion above, it can be concluded that the da'wah approach is now not enough with conventional methods. Technological developments are increasingly fast demanding adjustments. In this digital era, da'wah must be more optimally delivered through social media, because the millennial generation is more likely to use social media in the form of the internet, such as interactive applications, such as what sap, YouTube Instagram, Line and Twitter. Therefore, Da'i must be creative in packaging media and da'wah facilities so that it is easily accepted by the millennial generation that is instantaneous.

Social media is as much as possible in order to reach a wider mad'u so that more da'wah messages are absorbed. First, da'wah is an obligation for every Muslim. Da'wah must be done in ways that are wise, not confrontational, non-discriminatory and not provocative in accordance with the appeal of Qs. An Nahl: 125. Secondly, social media is considered effective as a means of da'wah. Da'wah with social media must pay attention to ethics and social media norms. So that it really brings benefits, not the other way around causing problems.

\section{References}

Al-Qur'an al Kariem (https://ppidkemkominfo.files.wordpress.com/2012/11/uu-no-11-tahun2008-tentang-ite.pdf).

A. Ghani. Bustani at el., Al-Qur'an Dan Tafsirnya, Semarang: PT Citra Effhar, 1993

Akram Dhiya' al-'Umary, Al-Mujtama' al-Madny fi 'Ahd an-Nubuwah,(Madinah,al-Majlis alI'lamy, 1983)

Al-Maraghi. Ahmad Musthafa, Tafsir Al-Maraghi, Kairo: Musthofa Al-Bab Al-Halab, 1946

Al-Qohthoniy. Sad 'Ali Ibn Muhammad.fiqhu al-da'wah fi shahîh al-Imam al-Buhkariy, Maktaba Syamela.

Aripudin. Acep, Dakwah Antarbudaya, (Bandung: PT. Remaja Rosadakarya, 2012

Ar-Rifa'i. Muhammad Nasib, Ringkasan Tafsir Ibnu Katsir, (Jakarta: Gema Insani, 2000), juz. II, Ash-Shabuni. Muhammad Ali, Shafwatu at-Tafasir, (Bairut: Dar al-Qur'an al-Karim, 1981), juz. II As-Samarqadi. Abul Laist, Tafsir As-Samarqandi, (Libanon: Dar Al-Kutub Al-Ilmiah, 1993), juz. II

Aziz. Mohammad Ali, Ilmu Dakwah, Jakarta:Kencana, 2006

Ensiklopedi Islam (Jakarta, PT Ichtiar Baru van Hoeve, 2003, jilid I

Fath al-Bayânûniy. Muhammad Abû al-, al-madkhal ilâ 'ilmi al-da'wah, (Beirut: Muassatu alRisâlah,1995) 3rd print

Hafidhuddin. Didin, Dakwah Aktual, Jakarta: Gema Insani Press, 2000

Hamka, Tafsir Al-Azhar, Jakarta: Pustaka Panjimas, 1983, juz. 13 \& 14

Ibrahim Unais at el, Al-.mu'jam al-Wasith,Cairo:al-Majma' al-Lughat al-'Arabiyah,1972,Jil:

1.h.286-287. Toha Yahya, Omar, Ilmu Dakwah, Jakarta: Wijaya, 2004

JAKIM, Tafsir Pimpinan Ar-Rahman,Kuala Lumpur:Darul Fikri, 2001

Kafie. Jamaludfin, Pengantar Ilmu Dakwah, Madura: Karunia Surabaya,1988

Mulyati. Ani, Panduan Optimalisasi Media Sosial untuk KementerianPerdagangan RI, (Jakarta: Pusat Humas KementerianPerdagangan, 2014

Munawwir M. Warson, Kamus al Munawwir, (Surabaya: Pustaka Progresif, 1994), p. 439

Omar. Toha Yahya, Ilmu Dakwah, Jakarta: Wijaya, 2004

Pimay. Awaluddin, Paradigma Dakwah Humanis, Semarang: Rasail, 2005 
Rais. Amien, Cakrawala Islam Antara Cita dan Fakta, Bandung: Mizan,1999

Shihab. M. Quraish, Tafsir Al-Misbah, Jakarta: Lentera Hati, 2002, vol. VII, p. 386

Sulthon. Muhammad, Desain Ilmu Dakwah Kajian Ontologis, Epistemologis dan Aksiologis, (Yogyakarta: Pustaka Pelajar,2003), p. 15

Suparta. Munzier and Harjani Hefni, Metode Dakwah, (Jakarta: Rahmat Semesta, 2006), $2^{\text {nd }}$ print

Tasmara. Toto, Komunikasi Dakwah, (Jakarta: Gaya Media Pratama, 1997), p. 43.

Zaidan. Abdul Karîm, Ushûlu al-da'wah, versi e-book, 1975 